\title{
IMPLEMENTATION OF RISK MANAGEMENT IN THE MALAYSIAN CONSTRUCTION INDUSTRY
}

\author{
Lee Chun Siang and Azlan Shah Ali \\ Faculty of Built Environment, University of Malaya \\ 50603, Kuala Lumpur, Malaysia \\ asafab@um.edu.my
}

\begin{abstract}
Risk and uncertainty constantly plagued construction industry compared with other business activities due to its characteristics of complexity, dynamic and time consuming. As risk management is predicting the unpredictable, it is one of the most vital management tools to cope with project risks and uncertainties. Risk management is important to create values to a project and improve project performance in term of cost, time and quality. However, systematic risk management is not implemented in most of the existing construction companies in Malaysia. This situation leads to project failure such as cost overrun, schedule slip and poor quality performance. This article focuses on the implementation of risk management in Malaysian construction industry and attempt to establish the relationship between risk management and project performance. The data were obtained from desk works, followed by semi-structured interviews involved risk management personnel from 3 selected local construction companies. Findings concluded that risk management practices in Malaysian construction companies were relatively low and lack of standardisation. However, there were little evidence shows that project performance improved by implementing risk management exercise.
\end{abstract}

Keywords: risk management; Malaysia; project performance

\subsection{Introduction}

It is essential to understand exactly what is meant by risk before it can be managed. Risk and uncertainty are inherent in all construction projects, regardless its size (Carr and Tah, 1999; Abdul Rahman Ayub, Nordiana Mohd Isa and Ilias Said, 2007). Construction project is plagued by risk due to their nature of construction business activities, processes, environment and organization (Akintoye and Macleod, 1997). They continue claimed that those within the construction industry are constantly faced with unpredictable and unfavourable factors. In general, construction project requires enormous amounts of turnover rate, resources and professionals from different fields and skills and they are interrelated to each other. Such complexity further compounded by the unique features which are distinctive end product and on site production. Thus, coordination and communication among the ad-hoc project team is essential when managing the risks.

The Association for Project Management (2000) stated that risk is unavoidable in construction projects and thus, risk management is a hastily developing management tool in construction project due to the realization of its importance as an integral part of project management. Risk management is one of the most vital procedures and capability way in coping with project risks and uncertainties. In order to rescue the poor reputation of construction industry in project performance, the right implementation of risk management is essential. With the implementation of risk management, the common problem in construction projects such as delay in project delivery, over budget, unsatisfactory product quality, unsafe working environment and etc. needs can be eliminated. Therefore, it could be argued that risk management is important especially during the decision making process with regard to risks. 
However, it is not easy to achieve effective risk management in a construction project. Effective risk management is the major challenges to the project managers. Although project managers cannot predict the future, they can anticipate risk that inherent in a project and manage the risk before it happens (Tserng et al, 2009). However, Chapman (1999) stated that the tendency for risk management approach is over prescribed where they emphasized on techniques of risk management but not the risk identification process.

Tserng et al. (2009) mentioned that risk management must be carried out throughout the life cycle of the construction project, from initiation stage until the decommissioning of the project. Failure to manage the project risks throughout the life cycle of construction project will affect the poor project performance (Abdul Rahman Ayub, Nordiana Mohd Isa and Ilias Said, 2007).

On the other hand, Olsson (2008) stated that most of the existing construction project processes do not integral formal risk management in their project portfolio. To overcome such lack of formality in construction risk management, research aimed at effective risk management approach is increasing and has been the interest focus recently in order to have good project performance and emphasize contractual obligations. This is further supported by Kululanga and Kuotcha (2010) where they mentioned that low implementation of project risk management in practice causing the projects failing to meet deadlines, cost targets and quality performance.

However, to what extent the risk management practice could be able to improve performance of project in Malaysia is still inconclusive. Thus the aim of this paper is to investigate how risk management could affect the project performance in Malaysian construction industry.

\subsection{Risk Management}

Although risk is widely studied, no uniform definition for risk exists. In another words, definition for risk is still flawed. Generally, risk is the event which traditionally is likely to occur, and could negatively affect the project outcome in term of time, cost, quality and other relevant performance criteria (Olsson, 2008).

According to Carbone and Tippett (2004), it is critical to have a helpful technique to plan for and cope with construction risks and uncertainties. Such technique which is risk management should be easily understood, utilised and applied by the project team. In fact, risk management is predicting the unpredictable. It is a vital management tool which helps to control construction project risks (Mills, 2001). Similarly, The Association for Project Management (2000) defines risk management as the process which enables the analysis and assessment of project risks. It is the process created to mitigate and control the risks which are the barriers to the successful completion of project performance. Risk management is the process of identifying, evaluating and managing risks. Tang et al (2007) stated that risk management is an essential element of the decision making process in construction projects. Construction management researchers noted that risk management is an integral part of organisational process and not just as a set of tools and techniques ((IRM, AIRMIC and ALARM, 2002; Hamimah Adnan et al. 2008; Kululanga and Kuotcha, 2010). It is the process where the project team explicitly 
address the risks and uncertainties. Then, they systematically evaluate and analysis the risk based on the best information. Risk management is important to create value to the project team by unblock the successful project activities and portfolio. It will increase the likelihood of beneficial project performance in term of budget, schedule, and quality if risk management is appropriately commenced.

Risk management is a constant and developing management tool which must be carried out all the way through the organization's approach and execution of that approach (Raz and Michael, 2001). Risk management is not a one day off activity.

However, there is lack of sufficient data that can be referred when managing the project risk. This is due to the uniqueness of construction project, where there are no two identical projects. Therefore, risk management in construction industry is different from other industry where there are references to take up as an actuarial approach. Risk management in construction industry need an intuitive approach due to its variables such as technical, engineering, innovative, procurement and strategic content (The Association of Project Management, 2000).

IRM, AIRMIC and ALARM (2002) stated that there are many methods when managing the risk and it is impossible to set and fix it up. Thus, there is no any certain box ticking strategy or demonstrable process exists in risk management standard. Usually, the organisations themselves will create their own methodology, approach, and standard in managing the risk.

On the other hand, IRM, AIRMIC and ALARM (2002) mentioned that when dealing with the risks, it is better to address systematically all the risks regarding the past, present, in specific and future activities in the construction organisation. This is because the approach of risk management of is traditionally applied instinctively, based on judgement and previous experience of the practitioners. Such approach will cause the project risks remain embedded and flawed.

In fact, the ad-hoc project team of construction industry is contributed by different professionals with different task and role to perform. But yet they are tightly interrelated. Thus, each professional not only suffer the risk from their own execution but also influenced by the risk faced by other professionals (Tserng et al, 2009). Therefore, the commitment, participation, and communication of project team to the overall risk management process are very important to come out with the successful and well-done end product (Chapman, 1999).

According to Hamimah Adnan et al (2008b), as Malaysian construction industry has a bad reputation in managing the risk, risk management must be implemented to avoid project failure and project underperformance. As mentioned by Hamimah Adnan, Kamaruzaman Jusoff and Mohd Khairi Salim (2008), risk management includes proper risk mitigation after identified, evaluated and analyzed the risk events. Risk mitigation plan must capable to minimise the negative impacts with reasonable costs. More often than not, risk management is essential for Malaysian contractors to ensure the project success. 
In Malaysia, contractors apply simple, quick, reasonable and inexpensive methods during risk identification such as checklist methods and brainstorming sessions. Risk identification mode was different for different projects. Basically, it depends on the characteristic of construction projects and it must commence in the initial stage. Risk analysis requires personnel experience, training, risk management software and specialist advice to come out with appropriate response. For contractors in Malaysia, risk response is concentrated on risk events with high probability of occurrence and high impact. However, not all the companies carry out the adequate process of reporting, reviewing, and monitoring the continuing risk management activity (Norazian Mohd Yusuwan et al, 2008).

Norazian Mohd Yusuwan et al (2008) further stated that in the Malaysian construction industry, risk management is quite a new management concept. Zultakiyuddin Ahmad Rashid, Hamimah Adnan and Kamaruzaman Jusoff, (2008) emphasized that risk management is essential and necessary to achieve the project performance; however, Malaysian construction industry players do not reveal such urgency. In fact, construction industry players should be proactive in implementing risk management.

Moreover, Roshana Takim and Akintoye (2005) stated that risk management is still rhetorical in Malaysian construction industry due to insufficient knowledge. Besides, contractors are reluctant to implement risk management in order to minimize the operational cost of projects. Their awareness on benefits and importance of risk management is relatively low. Nevertheless, it is proven by Norazian Mohd Yusuwan et al (2008) that risk management is implemented by companies in the operation of construction activities, although the number of identifiable and effective risk management framework practitioner in Malaysia is only a small scale. However, formal risk management is implemented by companies with high reputation, stable financial status and involved in massive construction projects only. According to Zultakiyuddin Ahmad Rashid et al. (2008), risk management practice in Malaysian construction companies is different. It depended on the policies of company, resources allocated, nature of projects and so on. In fact, certain standardization on risk management should be executed to ensure that the least mandatory approach of risk management is applied.

Generally, through the literature review, the risk management process can be summarised as in Figure 1.

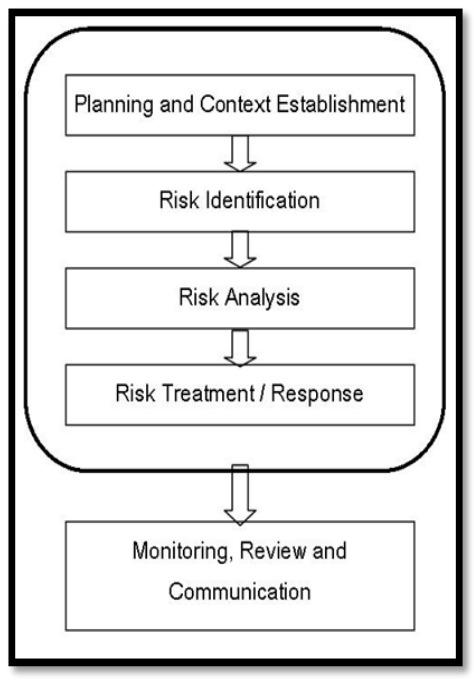

Figure 1: Risk management process. 
First, the background and environment of the organization must be understood through planning and context establishment. Secondly, risk identification sets out to pinpoint the risks that the project exposed to. All the comprehensively significant sources and causes of risks should be identified. Risk identification is stressed by researchers (Abdul Rahman Ayub, Nordiana Mohd Isa and Ilias Said, 2007; Mills, 2001; Carbone and Tippett, 2004) as the most important and difficult step in risk management process. After the risk has been identified, it should be arrange in a structured format, for instance, using diagram or table. Risk analysis is regarding the effect quantification of the identified risks. In addition, risk analysis involves the assessment of risk on its likelihood to occur, impact and seriousness of the risk towards construction activities. There are two methods to estimate the likelihood of risk occurrence and its possible impact, which are quantitative analysis and qualitative analysis (IRM, AIRMIC, and ALARM, 2002). According to Hamimah Adnan, Kamaruzaman Jusoff and Mohd Khairi Salim (2008), after the analysis is carried out, risk rating is given according to their magnitude of negative impact. Fourthly, Risk treatment is the step of selecting and identifying preventive measures to modify the project risks. According to Akintoye and Macleod (1997), there are five major elements in risk treatment, which are risk reduction, risk retention, risk transfer and risk acceptance. When selecting the appropriate risk treatment measures, it must ensure that the action will bring to effective and efficiency operation of the organization. Besides, cost versus benefit ratio is an important criterion when choosing the remedial action (IRM, AIRMIC and ALARM, 2002). Lastly, step of monitoring, reviewing and communication is essential to ensure the problems are anticipated and planned controls and responses are delivered.

\subsection{Relationship Between Risk Management And Project Performance}

The importance of practising risk management is to increase significant sustainable value to all the construction activities which is far in surplus of the cost to performing it. Risk management enhances the probability of success and maximise profitability, minimise the consequences of risky and uncertainty events in term of achieving the project objectives, and can seize the chances. According to Flanagan and Norman (1993), ultimately, importance of risk management is to enhance the project performance by avoiding the project from:

i. $\quad$ Failure to keep within cost budget/forecast/estimate/tender.

ii. $\quad$ Failure to keep within time stipulated for approvals, design, construction and occupancy.

iii. Failure to meet the required technical standards for quality, function, fitness for purpose, safety and environment protection.

According to the Association for Project Management (2000) and IRM, AIRMIC and ALARM (2002), not only the project team gains the benefits from risk management, but also the client, customers and potential end users of the construction projects. Based on the literature, benefits of risk management are as following:

i. Formulation of more practical strategy in terms of cost estimation and work of schedule through the better perceptive of the project.

ii. By having a better perception on project risks and their potential consequences, the risk response can be well-planned through allocation of risk to the compatible party to handle.

iii. Select the suitable type of contract 
iv. Improving decision making, planning and prioritisation and enable the efficiency of risk management and construction process.

v. By reflecting the risks in a contract, contractor can decide whether the project is financially sound or unsound.

vi. Through the structured information of previous project risks, better modelling of future project can be built up.

vii. Decrease the instability of the construction activities.

viii. Avoid unsatisfactory projects and to enhance margins.

ix. $\quad$ Protect credibility and reputation of company.

x. Maximising efficiency of construction activities and protect the continuity of operation.

In order to measure the performance of construction projects, performance indicators need to be identified. Due to the dynamic nature of construction projects, measuring performance of construction projects is a tough and thorny undertaking (Amran Md Rasli and Wan Maseri Wan Mohd, 2008). In Malaysia, according to Samiaah M. Hassen M. Al-Tmeemy, Hamzah Abdul-Rahman and Zakaria Harun (2010) and Sabariyah Din, Zahidy Abd-Hamid and Bryde (2010), the criteria of project performance which are cost, time and quality, are the basic elements of project success. However, these criteria are suitable to measure the project management success only, which during the delivery of construction. Atkinson (1999) stated that time and cost are effective indicator to measure success. Notwithstanding, quality is a phenomenon, where different parties has different perception on the term of quality. The broadest sense of quality might change along the life cycle of construction projects.

\subsection{Cost Performance}

Cost performance is the essential criteria of project performance because it represents the soundness of construction contract, profitability and productivity of contractors (Meeampol and Ogunlana, 2006; Amran Md Rasli and Wan Maseri Wan Mohd, 2008). According to Baloi and Price (2002) and Jin and Yean (2005), the dependent variables of cost performance is cost growth, which is the difference between planned budget and actual cost. If the difference between planned and actual cost is low, the cost performance of that project is considered successful.

\subsection{Time Performance}

According to Meeampol and Ogunlana (2006), time performance is as essential as cost performance, and both are strongly interrelated. This is due to delay in construction projects usually results in extra cost and further reduce the profitability of company. Kamrul Ahsan and Indra Gunawan (2010) stated that time performance can be measured through the difference between project planned duration and actual duration. Jin and Yean (2005) have named the dependent variables of time performance as schedule growth. If the construction progress followed the planned schedule, the project is considered as successful. Besides that, as stated by 
Meeampol and Ogunlana (2006), time performance does not only concern on completion of time construction, but also the sequence of construction work and its progress.

\subsection{Quality Performance}

Bryde (2003) found that different individuals have different expectations on the end product of construction projects. Client, contractor, architect and building user have different parameter to measure the quality although the measurement is against the same end product. Samiaah M. Hassen M. Al-Tmeemy, Hamzah Abdul-Rahman and Zakaria Harun (2010) stated quality as the requirement goals or initial project objectives. According to Chan and Chan (2004), quality is all about the entirety of features requisite by a product to meet the desired need and fit for purpose. To ensure the effectiveness and conformity of quality performance, the specification of quality requirements should be clearly and explicitly stated in design and contract documents.

Risk management is essentially influencing the successful of project performance (Jin and Yean, 2005). Effective risk management and successful project performance has an intimate relationship. Risk identification identified the potential risks that might influence the project objectives (Baloi and Price, 2002). Sundararajan (2004) stated that if risk events are not handling and managed properly, consequences like increasing the financing cost, changing the capital structure, delay the building or facility operation, overrun budget, lost the cash inflow, lead to liquidated damages claim, produce poor quality end product, involve rework after completion and so on might occur. Therefore, mitigation actions against these risks and uncertainties are vital to ensure achieving desired project performance.

The above literature points the risk management in overall and importance of risk management. However, it cannot provide a conclusive of current risk management practice in Malaysian construction industry and to what extent risk management affect project performance in Malaysian construction industry. Furthermore, research on relationship between risk management and project performance in Malaysian construction industry is still sparse.

\subsection{Research Methodology}

For this research, qualitative research was applied and case studies approach was used. The sampling for case studies was picked based on the Selected Sampling. This type of sampling was normally used for interview approach. The main criteria of respondents selection was they must implement risk management in the construction projects. The number of companies that implemented risk management in Malaysian construction industry was comparatively low, and it was mostly implemented by big companies. Thus, only listed construction companies were chosen. Nevertheless, not all listed construction companies were implementing risk management. Thus, inquiry regarding risk management implementation was done through phone calling and email. Only the companies that implemented formal risk management were shortlisted. 
Next, interview was made with the person in charge of risk management, which might be the project manager, risk manager or internal audit manager. They would answer the question based on their experience, knowledge and intuition regarding the implementation of risk management. There were three construction companies selected as case studies in this research to study on the risk management implementation and its benefits. These three companies were Company A, the subsidiary company of S P Setia Berhad Group in construction division, Company B and the other is public listed construction firm that the company has privacy policy that their name cannot stated as agreed during interview session, namely Company $\mathrm{C}$. These three companies were construction firms that registered in Contractor Services Center (PKK) with Class A and in Construction Industry Development Board (CIDB) with Grade 7.

\subsection{Data Analysis And Discussion}

Setia Precast was concentrated on construction with Industrialize Building System (IBS). Company A and Company $\mathrm{C}$ were not only constructing building, but also infrastructures. The similarity between these three companies was they are constructing building. Questions in the interview session were answered based on the building construction projects only. Details to be analysed in each case study are its risk management practice and project performance on time, cost quality after implementing risk management

\subsection{Case study 1: COMPANY A}

Interview session was done with the Group Internal Audit Manager. The company perceived risk in both negative and positive impact. Besides that, as construction projects involved various professionals and personnel in the company, risk management in the company were not under the scope of any department. Risk management was implemented in almost all departments, which including financial, project, planning and so on. However, there is no a centralize risk management committee or department. Generally, there were five main steps in risk management process that had been taken by the company, which were goal and context establishment, risk identification, risk analysis, risk evaluation and risk treatment. Risk management in the company was applied by referring to past, present, in specific and future activities in the organization. Besides, the company referred to the ISO 31000:2009, the standards guidelines and principles of risk management. The most difficult part in risk management was the co-operation of all operational people towards the risk management process. In order to overcome the difficulty, the initiative was to set the risk management process with real time operation. Physical risk and technical risk were the key risk events in construction projects of Company A. Cost performance was the priority for purpose of implementing risk management. It was followed by time performance, to ensure construction project can hand over on time. Risk management to ensuring quality performance was considered as the least important among the three project performance. After implementing risk management, the variation of cost and schedule growth was within the acceptable level, which is around 5\% to $10 \%$. The percentage of variation for both cost and schedule was reduced after implementing risk management. As risk management was implemented for 15 years in the company, the exact percentage of improvement was vague. However, the organization of the company assumed that it was already an excellent outcome of risk management. The overall impact of risk 
management on time and cost performance was satisfied by the company, which the satisfaction rating is 3.67 over 5(very satisfied). For the quality performance, the company admitted that risk management did not improve the quality performance much. This may due to the company was more focusing on time and cost performance if compared with quality performance. In the view point of Company A, the benefit of risk management was management decisions were supported through the analysis of data, allowing estimations to be made with greater confidence.

\subsection{Case study 2: COMPANY B}

The interview session was conducted with the Project Manager. The company defined risk as the threat and barrier to project success. In Company B, objectives of the company were supported through risk management in the aspect of below:

i. Provide a framework that enables future activities to take place in a consistent and controlled manner

ii. Improve decision making

iii. More efficient use and allocation of resources

iv. Protect and enhance asset and reputation of company

v. Maximize operational efficiency.

For every construction projects, risk management committee was formed to implement risk management effectively. Risk management plan was prepared for every construction projects in the early stage before the tendering process. Board of Directors had overall responsibility for risk management function. Risk treatment plan was prepared when managing the risks. There were 7 main steps for risk management in Company B, which are understanding project objectives, risk identification, risk analysis, risk evaluation, risk treatment, monitoring and review, and risk reporting.

During the risk management process, problem usually arose from the development of risk management plan. It was impossible to foresee all risk events that might encounter during the life cycle of construction projects. In order to reduce the problem, risk management committee that comprises of head of departments was established. Their tasks were to identify the risks from various aspects and to ensure the information of risk management was reached to all subordinates in the department. Economic risk and financial risk had the highest probability of occurrence among the risk categories in Company B.

On the other hand, Company B ranked the importance of risk management in sequence from time, cost to quality performance. Time performance had the top priority as the importance of risk management as the main objective of IBS was to reduce the construction time. As the construction cost by using IBS was slightly higher than conventional cost, it was important to ensure the stability of cost performance. Building with IBS system usually will have less defect and higher quality performance, thus the company did not worry much on the quality performance. After implementing risk management, the variation of cost and time growth was around 5\%. This indicates that risk management aided to improve the project performance as the variation is quite low. Overall cost performance was rated as 4.33 (satisfied). Time performance was rated as the same as 
cost performance. For the quality performance, it was perfect in the delivery of construction projects of Company B. With risk management, the management was very satisfied with the quality of end products. It was rated 5 over 5 , which was the full marks. Other than that, risk management was beneficial to Company B by giving an increased understanding of the risks in the projects. Then, any unwanted events or activities could be avoided. The potential impacts can be known at the early stage and mitigation action can be carried out on time to ensure the project success. In addition, it was essential to minimize the interruption of construction activities.

\subsection{Case study 3: COMPANY C}

Interviewee of Company $\mathrm{C}$ was the risk manager. The company started to emphasis implementation of formal risk management around in the 1998 after the global economic crisis by the publication of risk management policy and handbook of the Company. The Company perceived risk as the event that might occur with both positive and negative impact to project objectives and performance. There were 5 main steps in the risk management process of company $\mathrm{C}$, which are risk identification, risk analysis, risk evaluation, risk treatment and risk report (report in Risk Management software). However, at the interval of risk management implementation, it was difficult to get buy-in from risk owner and difficult to appoint risk liaison, the person who responsible to manage the certain risk events. Therefore, the management must ensure that all risk owners updated their risk register into risk management software on quarterly basis. Risk categories that affected the cost performance like economic risk, financial risk and contracting risk occurred occasionally. Other risk categories that occurred occasionally were personal risk and managerial risk. Risk management was essential to achieve all three project performance criteria, which were cost, time and quality. No certain priority was set for these three project performance. Variation of cost growth and schedule growth for previous construction projects that integrated risk management were around $4 \%$ only. Prior to the implementation of formal risk management, the estimation of cost and schedule growth of the company by $\mathrm{Mr}$ Musa was around negative $15 \%$. The improvement of $9 \%$ was significant enough to prove the effectiveness of risk management towards improvement of cost and time performance. Satisfactory level of the Company on time and cost performance was the same, which was in level 4 , satisfied. The satisfactory level for quality performance was higher, which is 4.5 , more than satisfied. The top priority of implementing risk management in Company $\mathrm{C}$ was to protect the credibility and reputation of company.

\subsection{Discussion}

Although risk management was implemented in those three companies, the practice and approach was different. This may due to the different policies in the company. The risk management process for Company $\mathrm{A}$ and Company $\mathrm{C}$ was almost the same. For Company $\mathrm{B}$, the risk management process was more detailed and complete. This was due the company prepared risk management plan for every new project. Therefore, the risk management process was developed from time to time. Monitoring and reviewing step in the risk management process assisted the risk management committee to ensure everyone has accomplished their task and responsibilities in treating the risks. Company $\mathrm{C}$ had a more advanced approach in risk management. Company 
$\mathrm{C}$ was using risk management software to enhance the implementation of risk management. By using the software, a more effective communication and easier monitoring for the management were achieved. Compared with Company C, Company A and Company B were using traditional method, which was recording the risk events in risk register in the hard copy. Thus, it was difficult to update all personnel on the latest discovery or issues.

Alternatively, frequency of risk occurrence according to risk categories in pervious building construction projects of the companies was compared. Chart 1 indicates the frequency of risk occurrence according to risk categories in 3 case studies.

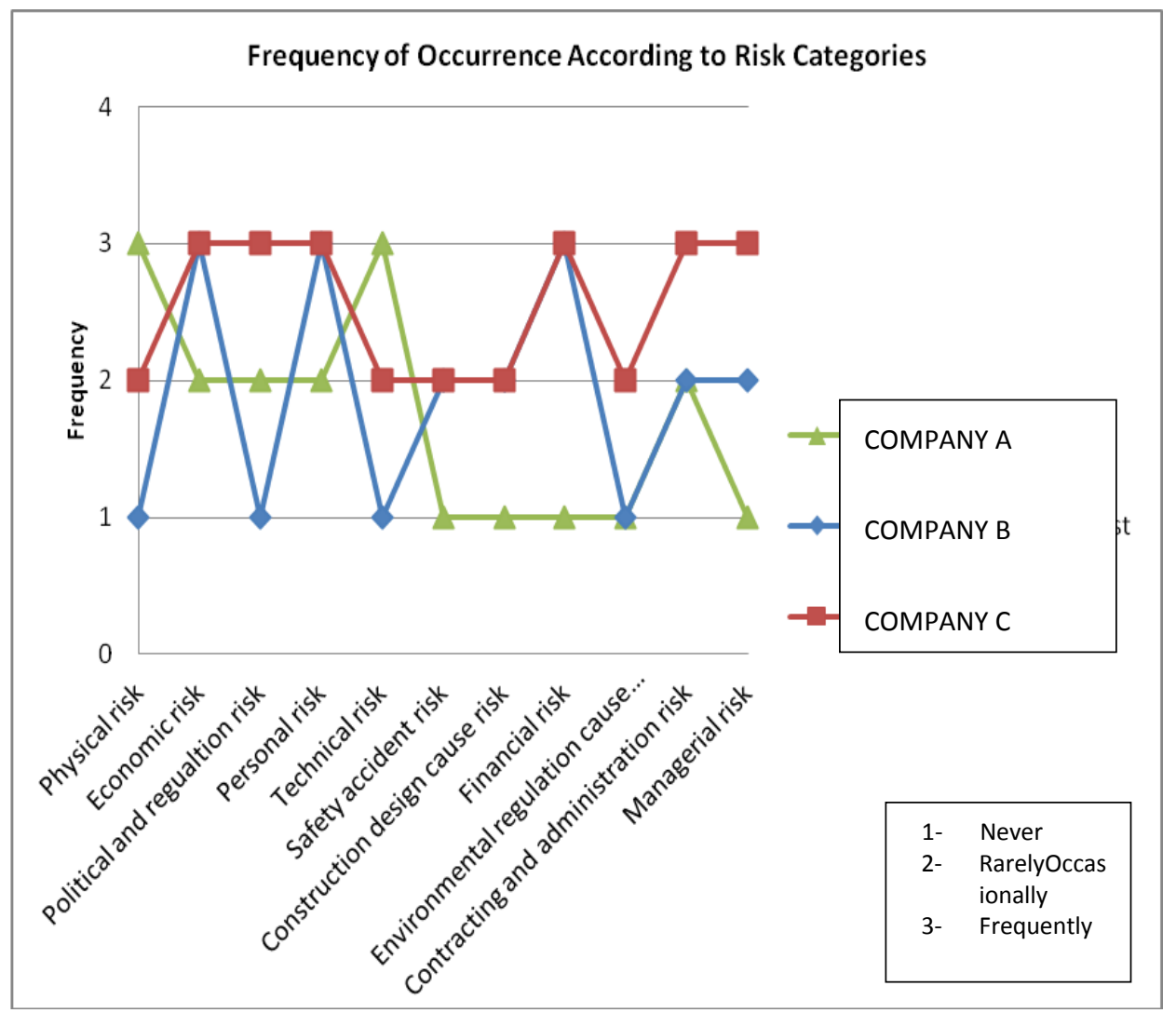

Chart 1: Frequency of risk occurrence according to risk categories in 3 case studies.

From the chart above, it obviously shows the trend of risk that plagued the building construction project in 3 companies is totally different. This may due to the different nature and characteristic of building construction projects in different companies. On the other hand, different company had different priority in the criteria of project performance to be achieved in conjunction with implementation of risk management. Overall, cost performance was the top priority to be achieved. Second was time performance and last was quality performance.

Risk management in building construction projects led to a lower variation of cost and schedule growth in projects of those three companies. Average variation of cost and schedule growth in construction projects of Company $\mathrm{C}$ was the lowest, which was $4 \%$. It was next followed by Company $\mathrm{B}, 5 \%$. In Company $\mathrm{A}$, the 
variation was comparatively higher, which was $5 \%$ to $10 \%$. This may due to the ineffectiveness risk management system was the Company A. Company B had formal risk management committee and Company C had risk management software to enhance the risk management practice in construction projects. However, risk management practice in Company A was comparatively unorganized.

Satisfactory level of the management on overall building construction projects is shown in Chart 2.

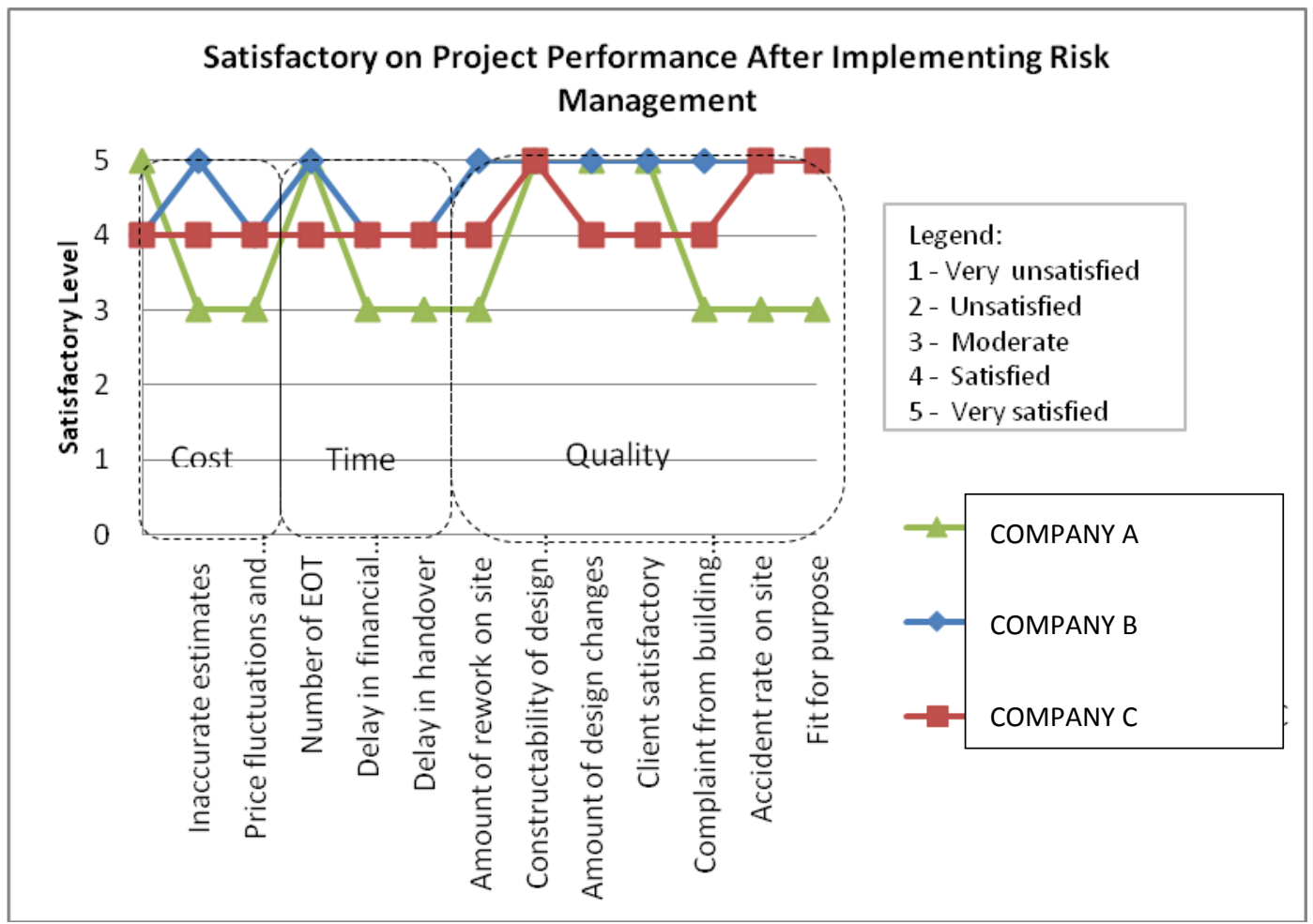

Chart 2: Satisfactory on project performance.

Referring to the chart above, overall project performance in Company B was the best among the three companies. Then it was followed by Company C. Project performance in Company A was not very satisfied by the management. The scenario here was similar to variation of cost and schedule growth which discussed previously. For the satisfactory level of time and cost performance in those three companies, it was found that the average score for both performances was the same (Company A: 3.7, Company B: 4.3, and Company C: 4). This was consistent with the percentage variation of cost and time growth for the companies. It indicated that time and cost performance had high correlation.

Lastly, the ranking for degree of importance of risk management based on identified benefits by those three companies is surprisingly found that is almost the same (refer Table 2). 
Table 2: Ranking of identified benefits based on degree of importance.

\begin{tabular}{|l|c|c|c|}
\hline \multicolumn{1}{|c|}{ Identified benefits } & Company A & Company \\
& B & Company \\
\hline Protect credibility and reputation of company & 1 & 2 & 1 \\
\hline Improving decision making, planning and prioritisation & 2 & 1 & 3 \\
\hline $\begin{array}{l}\text { Formulation of more practical strategy in terms of cost } \\
\text { estimation and work of schedule }\end{array}$ & 3 & 3 & 2 \\
\hline $\begin{array}{l}\text { Risk response can be well-planned through allocation of } \\
\text { risk to the compatible party to handle. }\end{array}$ & 4 & 4 & 5 \\
\hline Project is financially sound or unsound / Project viability & 5 & 6 & 4 \\
\hline Decrease the instability of the construction activities. & 6 & 7 & 7 \\
\hline Select the suitable type of contract & 7 & 5 & 9 \\
\hline $\begin{array}{l}\text { Maximising efficiency of construction activities and } \\
\text { protect the continuity of operation. }\end{array}$ & 8 & 8 & 6 \\
\hline Better modelling of future project can be built up. & 10 & 9 & 8 \\
\hline Avoid unsatisfactory projects and to enhance margins & 9 & 10 & 10 \\
\hline
\end{tabular}

From the table, it shows that the perception of the companies on benefits of risk management was quite similar. There was no big variation between the rankings given. Generally, all 3 companies agreed that protect credibility and reputation was most important outcome of risk management. It was due to all those three companies are public listed company or subsidiary company. With high credibility and reputation, clients and public will have high degree of confidence on the end products. If the projects were able to achieve its objective and performance, reputation of the company can be enhanced. In contrast, the risk management in those three companies is not aimed to enhance the margins.

\subsection{Conclusion}

It was found that risk management is essentially influencing the successful of project performance as risks arise in construction projects have impacts on the project performance. Different risk management practice will have different effects on project performance. This was proved in the case studies. Risk management practice in Company B and Company $\mathrm{C}$ was more comprehensive and inclusive than Company A. Therefore, project performance in Company A was comparatively dissatisfied. Higher variation of cost and schedule growth and poorer project performance of Company A indicated that risk management practice affect the project performance. As the 3 selected companies were subsidiary public listed companies, reputation and credibility of the company was significant to be the top benefit of risk management. Risk management is also important to ensure appropriate and accurate decision making and planning in construction industry could be made on time. 


\subsection{References}

Abdul Rahman Ayub, Nordiana Mohd Isa, \& Ilias Said. (2007). Identification of Construction Industry Risks in Malaysian Construction Industry (Case Study: Penang Area), Proceeding of MICRA 2007, In: Proceedings of Management in Construction Research Conference, Faculty of Architecture, Planning \& Surveying, Universiti Teknologi Mara Malaysia (UiTM). pp B-1-1- B-1-12

Akintoye, A.S., \& Macleod, M.J. (1997). Risk analysis and management in construction. International Journal of Project Management, 15(1), 31-38.

Amran Md Rasli, \& Wan Maseri Wan Mohd. (2008). Project performance framework: the role of knowledge management and information technology infrastructure. Asian Journal of Business and Accounting, 1(2), 39-64.

Baloi, D., \& Price, A.D.F. (2003). Modelling global risk factors affecting construction cost performance. International Journal of Project Management, 21, 261-269.

Bryde, D.J. (2003). Modelling project management performance. International Journal of Quality \& Reliability Management, 20(2), 229-254.

Carbone, T.A., \& Tippet, D.D. (2004). Project risk management using project risk FMEA. Engineering Management Journal, 16, 4, 28-35.

Carr, V., \& Tah, J.H.M. (1999). A fuzzy approach to construction project risk assessment and analysis: construction project risk management system. Advance in Engineering Software, 32, 847-857.

Chan, A.P.C., \& Chan, A.P.L. (2004). Key performance indicators for measuring construction success. Benchmarking An International Journal, 11(2), 203-221.

Chapman, R.J. (1999). The controlling influences on effective risk identification and assessment for construction design management. International Journal of Project Management, 19, 147-160.

Flanagan, R., \& Norman, G. (1993). Risk Management and Construction. Blackwell, UK.

Hamimah Adnan, Kamaruzaman Jusoff, \& Mohd Khairi Salim. (2008). The Malaysian construction industry’s risk management in design and build. Modern Applied Science, 2(5), 27-33.

Hamimah Adnan, Mohd Nidzam Rahmat, Nur Fatanah Nadiah Mazali, \& Kamaruzaman Jusoff. (2008b). Risk management assessment for partnering projects in the Malaysian construction industry. Journal of Politics and Law, (1)1, 76-81.

Hamimah Adnan. (2008). An assessment of risk management in joint venture (JV) in Malaysia. Asian Social Science, 4(6), 99-106.

IRM, AIRMIC, \& ALARM (2002). A Risk Management Standard.

Jin, X.H., \& Yean, F.Y.L. (2006). Key relationship-based determinants of project performance in China. Building and Environment, 41, 915-925.

Kamrul Ahsan, \& Indra Gunawan. (2010). Analysis of cost and schedule performance of international development projects. International Journal of Project Management, 28, 68-78.

Kululanga, G., \& Kuotcha, W. (2009). Measuring project risk management process for construction contractors with statement indicators linked to numerical scores. Engineering, Construction and Architectural Management, 17, 4, 336-351. 
Meeampol, S., \& Ogunlana, S.O. (2006). Factors affecting cost and time performance on highway construction projects: evidence from Thailand. Journal of Financial Management of property and Construction, 11(1), 3-20.

Mills, A. (2001). A systematic approach to risk management for construction. Structural Survey, 19, 15, $245-$ 252.

Norazian Mohd Yusuwan, Hamimah Adnan, Ahmand Faris Omar, \& Kamaruzaman Jusoff. (2008). Clients' perspectives of risk management practice in Malaysian construction industry. Journal of Politics and Law, 1, 3, 121-130.

Olsson, R. (2008). Risk management in a multi project environment. International Journal of Quality and Reliability Management, 25, 1, 60-71.

Raz, T., \& Michael, E. (2001). Use and benefits of tools for project management. International Journal of Project Management, 19, 9-17.

Roshana Takim, \& Akintoye, A. (2005). Process improvement of construction projects in Malaysia: analysis case studies. Proceedings of the $2^{\text {nd }}$ Scottish Conference for postgraduate researchers of Built and Natural Environment (PRoBE) 16-17 November, Glasgow Caledonian University, 263-273.

Sabariyah Din, Zahidy Abd-Hamid, \& Bryde, D.J. (2010). ISO 9000 certification and construction project performance: The Malaysian experience. International Journal of Project Management.

Samiaah M. Hassen M. Al-Tmeemy, Hamzah Abdul-Rahman, \& Zakaria Harun. (2010).Future criteria for success of building projects in Malaysia. International Journal of Project Management.

Sundararajan, S.K. (2004). Project performance-based optimal capital structure for private financed infrastructure projects. Unpublished doctor of philosophy dissertation, University of Maryland, Maryland.

Tang, W.Z., Qiang, M.S., Duffield, C.F., Young, D.M., \& Liu, Y.M. (2007). Risk management in Chinese construction industry. Journal of Construction Engineering and Management, 133, 12, 944-956.

The Association for Project Management. (2000). Project Risk Analysis and Management.

Tserng, H.P., Yin, S.Y.L., Dzeng, R.J., Wou, B., Tsai, M.D., \& Chen, W.Y. (2009). A study of ontology-based risk management framework of construction projects through project life cycle. Automation in Construction, 18, 994-1008.

Zultakiyuddin Ahmad Rashid, Hamimah Adnan, \& Kamaruzaman Jusoff. (2008). Legal framework on risk management for design works in Malaysia. Journal of Politics and Law, 1(2), 26-32. 